This is the authors' final version of the paper that was used by the publishers to typeset the published paper. This paper was published online in 2016 by

Business History DOI: http://dx.doi.org/10.1080/00076791.2015.1128896. It will be published in print in Volume 58 of Business History.

\title{
Strategic Manoeuvres and Impression Management: Communication Approaches in the Case of a Crisis Event
}

\author{
O’Connell, B., De Lange, P., Stoner, G., Sangster, A.
}

\begin{abstract}
This historical study examines the actions of the Australian former asbestos company, James Hardie, when faced with a potentially ruinous corporate scandal between 2001 and 2007. The company became vilified as public awareness grew of the damage to public health its use of asbestos had caused. In response, it setup a knowingly underfunded compensation fund supported by a strategy of misinformation and denial. Its actions are analysed using Oliver's typology of strategic responses and theories of crisis management and crisis communications, providing insights into the company's motivations for adopting strategies that took it to the brink of financial collapse.
\end{abstract}

\section{Introduction}

This subject of this study is the Australian asbestos company, James Hardie, which found itself fighting for its survival throughout a lengthy period of medialed criticism as its products became publically recognised as killing people while it responded with defiance. The confrontation reached crisis levels in the late 1990s/early 2000s and culminated in the findings of a public inquiry being published in 2004 that confirmed the extent to which the company had breached acceptable practice in maintaining its innocence and evading responsibility. Ultimately, the company survived, but at considerable cost, not just to it, but to the thousands who suffered and died as a result of its actions.

For long-term survival, businesses must be flexible and inventive in response to a variety of threats, including changes in the marketplace, new entrants, and competing products and services, both new and old. While many do so in the short and medium term, relatively few survive longer than a few decades without substantial change. This can be seen regularly in the changing landscape of the stores in the major streets of cities across the world, as tastes change and businesses fail to react quickly enough with changes in their approach and to the products and services they sell. The decline may be slow and gradual, or it can be rapid, as in the case of the world's major bookstores, most of which have closed over the past decade as they failed to complete with the twin threat of internet-based outlets and electronic readers. However, in some cases, it is not just the nature of competition and changes in the marketplace that threaten survival.

Legislation may be introduced for a variety of reasons. In the case of products found to affect the health of those exposed to them it is usually a twostep process, with lobbying and litigation preceding the introduction of legislation, something that only occurs once evidence of harm is available, often a considerable time after victims first begin to suffer and complain. Cigarette manufacturers, for example, have been the target of health-issues-led lobbying and litigation for much longer than legislation has been in place restricting their 
use, and so have manufacturers and users of another product, asbestos. Asbestos was used routinely in building construction, and in products sold to do-ityourself enthusiasts as recently as the late- $20^{\text {th }}$ century. In the US, a ban on use of some asbestos materials was introduced in 1973, but its use is still not completely prohibited. Elsewhere, although Asbestos Industry Regulations were issued in 1933' ${ }^{1}$, it was not until 1999 that its use was banned in the UK. In Australia, the first asbestos regulations were introduced in the $1970 \mathrm{~s}^{2}$ but its use was not prohibited until 2003. The European Union banned use of asbestos in 2005. Where products that damage health are concerned, lobbying and litigation do not stop with the passing of legislation. One damages-limitation tactic adopted by companies that are, or expect to be found liable for the use of such products, is the establishment of a trust fund to cover any compensation claims and judgments made against it.

One asbestos-related example is from the UK, the Turner \& Newall group $(T \& N) .^{3} T \& N$ was aware of health concerns from the early decades of the $20^{\text {th }}$ century and, following the much reported and discussed death of one of its workers from asbestos poisoning in 1924, ${ }^{4}$ it set-up an internal liabilities fund for worker compensation in 1931. The perceived need for the scheme was diminished but not eliminated by the establishment of the UK Government's National Insurance scheme in 1948. However, the liabilities were not considered to be a serious concern for survival of its business: "until at least the 1960s the company never adequately compensated workers" [even though] "the board [of directors] was generous to its shareholders, especially to the holders of the ordinary shares". ${ }^{5}$ Nevertheless, by the early 1980s, T\&N had come to view asbestos-based compensation claims as a clear and publicly admitted risk. ${ }^{6}$

In Australia, it took longer for asbestos companies to recognise the health issues relating to asbestos, that it was killing people, never mind making them ill; and even longer for them to acknowledge them in the form of recognising significant corporate liabilities. As mentioned at the beginning of this Introduction, the subject of this paper is one such Australian company, James Hardie Group (JH), a company that "lag[ged] behind T\&N, in terms of the shifting meaning ascribed to asbestos". ${ }^{7}$

This paper presents a historiography of James Hardie. It looks at the institutional processes that impacted upon it when faced by litigation relating to asbestos exposure, and considers the disclosures and actions it adopted. In order to distinguish and clarify the various strategic responses of the company, this study adopts Oliver's institutional theory model which defines five forms of

\footnotetext{
1 Tweedale and Hansen, "Protecting the workers".

2 ASCC, "Asbestos management and control".

3 See, for example, Jeremy "Corporate Responses"; Warren, "The Enforcement"; Tweedale and Hansen, "Protecting the workers"; Tweedale and Warren, "A Case in Point"; Tweedale and Jeremy, "Compensating the Workers".

4 Tweedale and Hansen, "Protecting the workers".

5 Tweedale and Jeremy, "Compensating the Workers", 113-114.

${ }^{6}$ Moerman and van der Laan, Accounting and Long-tail Liabilities; Moerman, van der Laan, and Campbell, "A tale".

7 Moerman, van der Laan, and Campbell, "A tale”, 983.
} 
organisational reaction to pressures toward conformity: manipulation, defiance, avoidance, compromise, and acquiescence. ${ }^{8}$ Circumstances dictate whether any one, or a combination of these strategies, may be appropriate at any given time. Acquiescence is the typical approach ${ }^{9}$ but, in the case of James Harvey Group, having tried to isolate the company from any asbestos-related liability by relocating its operations overseas, it then adopted a solution consistent with new institutional sociology (NIS) whereby it adopted "structures and procedures that are valued in [its] social and cultural environment... in order to achieve legitimacy and to secure the resources that are essential for [its] survival".10

Taking its lead from T\&N's internal liabilities fund, JH's compensation scheme was far more complex: a special purpose fund intended to quarantine the company and, in particular, its assets, from potential claimants. ${ }^{11}$ It was named, the 'Medical Research and Compensation Foundation' (MRCF). When created in 2001, it was knowingly under-resourced. In response, the company attempted to manipulate perceptions of the capability of the fund to meet the liabilities it was supposed to address. Over the next six years it variously used manipulation, defiance, avoidance, and compromise to finally reach an arrangement acceptable to itself and its key stakeholders.

Four research questions are addressed in the course of this study:

1. What was the nature of the actions taken by the company in dealing with the asbestos issue during the period from 2001 through to the settlement with asbestos sufferers agreed in February 2007?

2. To what extent did JH's public disclosures pertaining to its asbestos liabilities change across this period?

3. What factors motivated the actions taken by the company?

4. How might the changes in actions and public disclosures taken by JH be explained by the corporate crisis management and crisis response communications literature?

In addressing these four questions, annual report disclosures, company media releases, and evidence presented to a high-profile public inquiry into the James Hardie Group, the Special Commission of Inquiry into the Medical Research and Compensation Foundation ${ }^{12}$ are used to present and analyse the historiography of the company's corporate disclosures, revealing detailed insights into the changing strategies employed by this organisation in dealing with the issues it faced.

\subsection{Contribution}

\footnotetext{
8 Oliver, "Strategic Responses".

${ }^{9}$ For example, Guerreiro, Rodrigues, and Craig, "Voluntary adoption of IFRS".

10 Ribeiro and Scapens, "Institutional theories", 96.

${ }^{11}$ In contrast, many former asbestos manufacturers including the US companies Johns Manville and Federal-Mogul (who had acquired the UK asbestos company Turner \& Newel) had initially sought to remove themselves from liability to claimants through the mechanism of strategic bankruptcy.

12 The Special Commission of Inquiry into James Hardie Group was a judicial inquiry commissioned on the $12^{\text {th }}$ February 2004 by the New South Wales State Government.
} 
This paper contributes to the business history, institutional, crisis management, and crisis communications literature in several ways. Firstly, it presents details of how a major national company managed its way through a potential minefield of litigation. In doing so, it is one of only a few studies that examine the volatile and pressured environment that evolves when a highly publicised product liability scandal occurs. Previous studies have generally examined the voluntary disclosure responses of organisations as a means by which they hope to repair organisational legitimacy in the eyes of their stakeholders. ${ }^{13}$ Analysis in those studies has generally been limited to the effects of the institutional environment on structural conformity and isomorphism, with only a limited assessment of the role of active agency and resistance. ${ }^{14}$ In contrast, the present study uses Oliver's typology of strategic responses ${ }^{15}$ to categorise particular responses by James Hardie over the six-year period when it was actively seeking to establish a trust to quarantine itself from litigation. It does so by examining a situation where active agency and resistance were at the core of the organisation's strategic response to the threats that it faced, one that involved a specific mechanism of choice, an aspect of new institutional sociology on which the literature has been largely silent. ${ }^{16}$

Secondly, it connects theory and research from multiple domains including crisis management, crisis communications, and strategic response by focussing upon an unsuccessful attempt at managing public expectations, rather than the dominant approach in this literature that has a focus upon how corporations successfully manage public expectations around scandals of this type. ${ }^{17}$ Furthermore, it is rare for a study of such a situation to be conducted through the lens of both data sourced from the company itself and an independent Commission of Inquiry.

Thirdly, while some studies into product liability scandals have been located elsewhere, such as the studies of T\&N in the UK, most of these studies have focused on the US and therefore reflect a particularly litigious environment that results in the actions of corporations and their alleged victims being heavily influenced by its very existence. The US legal system allows Chapter 11 bankruptcy protection which has readily been employed by asbestos implicated corporations in that jurisdiction. In contrast, the present study contributes to this body of literature by examining a product liability case in a different and less litigious environment, Australia.

Finally, this study complements the James Hardie studies of Moerman \& van der Laan ${ }^{18}$ and Moerman, van der Laan, and Campbell ${ }^{19}$ that have examined the

\footnotetext{
13 See, for example, Samkin and Schneider, "Accountability".

14 For example, Oliver, "Strategic Responses"; Arroyo, "Management accounting change".

15 Oliver, "Strategic Responses".

16 Modell, Jacobs, and Wiesel, “A process (re)turn?”, 455

${ }^{17}$ For example, Livesey, "Eco-identity”; Cornelissen, Bekkum, and Ruler, "Corporate communication".

18 Moerman and van der Laan, "Pursuing shareholder value"; Moerman and van der Laan, "Strategic Bankruptcy"; Moerman and van der Laan, "Accounting in organizations"; Moerman and van der Laan, Accounting and Long-tail Liabilities.

19 Moerman, van der Laan, and Campbell, "A Tale".
} 
company through the lens of strategic bankruptcy in considering how accounting might be implicated in the socialisation of risk management.

The next section presents a historiographical overview of the James Hardie Group. A description of the sources used in this study is then presented, followed by an overview of Oliver's typology of strategic responses which is then used to categorise and analyse the actions of the James Hardie Group between 2001 and 2007. The findings are then presented and discussed in the context of the crisis management and crisis communications literature, followed by use of Oliver's framework model to contextualise analysis of the motivation behind the actions of JH. This is followed by some concluding observations and consideration of the limitations of this study.

\section{The James Hardie Group}

James Hardie Group is an Australian company originally founded upon importing oils and animal hides in 1888. From 1915, it shifted its focus of operations to the mining of asbestos and the manufacture and distribution of asbestos products, including sheeting and roofing for construction. In doing so, it was a highly successful company and an iconic Australian building supply brand, establishing asbestos plants in five of the six Australian states: New South Wales, South Australia, Victoria, Queensland, and Western Australia. It was the $75^{\text {th }}$ largest Australian enterprise in $1964^{20}$ and a highly respected household name for much of the $20^{\text {th }}$ century. Despite the harmful physical effects of asbestos being known since the early decades of the $20^{\text {th }}$ century, this did not stop the company diversifying into and then expanding this lucrative activity during a period of around 60 years.

Its public persona suggested that the prospect of litigation and damages went unrecognised by the company for decades, just as it did by companies worldwide who were involved in extraction, production, or use of asbestos products. However, in 1978, the company began to look for a replacement for asbestos in its building products. It was recently claimed by the then managing director, David Macfarlane, that it did so for commercial reasons - asbestos was becoming too expensive - rather than health reasons. According to Macfarlane, the company was aware that "asbestos was in bad odour around the world" [in terms of media exposure of health concerns... but,] I thought the risk of it was overdone ... a media beat-up". ${ }^{21}$ However, despite Macfarlane's claims that the company thought it was all a bit of media over-reaction, that same year it took a tangible step towards protecting itself by placing asbestos health warnings on its packaging. ${ }^{22}$ This did not, however, deter victims from seeking compensation and it suffered a dramatic fall from grace when miners and other employees succeeded in linking their asbestos-related illnesses to JH in the 1980s. The first judgement against the company came in $1984^{23}$ and, in 1987, it ceased all its

\footnotetext{
20 Ville and Merrett, "The Development".

21 Higgins, "Hardie boss".

22 Sexton and Stephens, "Lives in the Dust".

${ }^{23}$ Asbestos Diseases Society of Australia, Asbestos.
} 
asbestos manufacturing activities, ${ }^{24}$ but the damage had already been done. The 1984 judgment and other litigation cases brought the extent of the company's failure to safeguard the health of its employees into the open. The company rapidly transformed from market 'darling' to 'villain' as damaging media coverage sought to demonise the company's reaction to damages claims by victims, particularly after it lost its first case for negligent damages in $1991 .^{25}$

Following the loss of that case, between 1995 and $1998 \mathrm{JH}$ went through dramatic structural, legal, and organisational change. Most of the assets of the original operating company were sold to other companies in the Group and the operating assets were transferred to a new entity domiciled in the Netherlands. In 1999, the New South Wales Dust Diseases Tribunal ruled that James Hardie had known of the dangers to health from asbestos dust since 1938 and, in 2000, the management of $\mathrm{JH}$ began considering a trust structure to quarantine the Group from its potential asbestos liabilities. A series of discussions were held between potential directors of the Trust and JH management between December 2000 and January 2001 and, in February 2001, the Board created the Medical Research and Compensation Foundation Ltd (MRCF). The media release issued at that time is shown in Exhibit 1. As can be seen, the management of JH expressed their confidence that the trust had sufficient funds to cover all potential asbestos claims.

Exhibit 1: James Hardie Media Release announcing the formation of the Medical Research and Compensation Foundation (MRCF)

16 February 2001

James Hardie Resolves its Asbestos Liability Favourably for Claimants and Shareholders

James Hardie Industries Limited (JHIL) announced today that it had established a foundation to compensate sufferers of asbestos-related diseases with claims against two former James Hardie subsidiaries and fund medical research aimed at finding cures for these diseases. The Medical Research and Compensation Foundation (MRCF), to be chaired by Sir Llewellyn Edwards, will be completely independent of JHIL and will commence operation with assets of $\$ 293$ million. The Foundation has sufficient funds to meet all legitimate compensation claims anticipated from people injured by asbestos products that were manufactured in the past by two former subsidiaries of JHIL.

JHIL CEO Mr Peter Macdonald said that the establishment of a fully-funded Foundation provided certainty for both claimants and shareholders. "The establishment of the Medical Research and Compensation Foundation provides certainty for people with a legitimate claim against the former James Hardie companies which manufactured asbestos products," Mr Macdonald said. "The Foundation will concentrate on managing its substantial assets for the benefit of claimants. Its establishment has effectively resolved James Hardie's asbestos liability and this will allow management to focus entirely on growing the company for the benefit of all shareholders."... In establishing the Foundation, James Hardie sought expert advice from a number of firms, including PricewaterhouseCoopers, Access Economics and the actuarial firm, Trowbridge. With

\footnotetext{
${ }^{24}$ Haigh, Asbestos House.

25 The case was brought on behalf of an employee who had worked for six months during 1960 in JH's Brooklyn, Victoria factory, where it had started production of asbestos cement building products in the 1920s (Asbestos Diseases Society of Australia, Asbestos; Allens Arthur Robinson, "Submissions of James Hardie").
} 
this advice, supplementing the company's long experience in the area of asbestos, the directors of JHIL determined the level of funding required by the Foundation. "James Hardie is satisfied that the Foundation has sufficient funds to meet anticipated future claims," Mr Macdonald said. When all future claims have been concluded, surplus funds will be used to support further scientific and medical research on lung diseases.

The fund, however, did not satisfy the company's critics and there followed a six-year period in which it slowly moved its position, initially when it was revealed that the fund was significantly underfunded, more so when a public inquiry revealed that the company had been aware of the underfunding from the outset. It finally agreed a level of support for victims of its asbestos-related activities that satisfied the demands of its key stakeholders in February 2007. It is the company's actions within this six-year period, from February 2001 to February 2007, that is the focus of this study.

\section{Sources of information}

The data used in this study are derived from analyses of the company's media releases, financial statement disclosures, compensation agreements, and associated documentation. These were obtained from a variety of sources, including the JH website (compensation agreement and associated documentation); Australian Securities Exchange website (JH media releases); the Report of a Special Commission in 2004 into James Hardie, and its numerous submissions; and the DatAnalysis database (financial statement disclosures). In addition, the Business Source Premier and Factiva databases were used to identify and examine press reports relating to JH between 2001 and 2007.

The next section considers the nature and motivations behind the actions taken by JH during this period.

\section{The Actions of the James Hardie Group 2001-2007}

In this section, in order to categorise its actions and determine how the company's strategy altered over the period, each act of the company is classified according to Oliver's framework of five potential strategies, or stages of organisational reaction to pressures toward conformity. ${ }^{26}$ Each of these strategies represents a progressively less active form of strategy substitution intended to deal with given institutional requirements and expectations: avoidance, defiance, manipulation, compromise, and acquiescence.

\subsection{Avoidance}

Oliver describes avoidance as an: "attempt to preclude the necessity of conformity... by concealing... nonconformity [i.e. disguising nonconformity behind a facade of acquiescence], buffering themselves from institutional pressures, or escaping from institutional rules or expectations [by exiting the domain within which pressure is exerted]. ${ }^{27} \mathrm{JH}$ had adopted an avoidance strategy in 1998 when it attempted to 'escape' by relocating the domicile of its operating companies

\footnotetext{
26 Oliver, "Strategic Responses".

27 Oliver, "Strategic Responses", 154-155.
} 
overseas, a move that was subsequently deemed to have been legally valid in the courts. However, its next attempt at avoidance, the creation of the MRCF, was a spectacular failure.

The establishment of the Foundation gave the appearance of conformity, but subsequent events revealed it to have been more of a smokescreen intended to deflect attention, avoidance not compromise, nor acquiescence. It began to unravel in October 2003 when JH found it could no longer conceal that the Foundation was inadequately resourced. The management of $\mathrm{JH}$ reacted by actively seeking to escape from the situation it was in through transferring much of the liability for asbestos claims onto the wider community. Firstly, the MRCF publicly conceded that there were likely to be insufficient funds within the Foundation to meet future potential claims ${ }^{28}$ and CEO Macdonald issued a statement indicating that any such shortfall was "a community-wide problem that is much larger than the Foundation's liabilities". ${ }^{29}$ At the same time, one of the $\mathrm{JH}$ companies, Amaca, ${ }^{30}$ was in the High Court arguing that the New South Wales State Government was partially liable for any asbestos claims because it had known about the possible health risks relating to asbestos yet had continued to utilise asbestos as a building material in the provision of public housing. ${ }^{31}$

Meanwhile, the company endeavoured to shift the blame for any errors in the funding calculations onto external consultants. In a media release of 29 October 2003, CEO Macdonald sought to avoid JH being held responsible for the under-resourcing of the Foundation: "over 10 years experience and eight years of actuarial reports were used" to arrive at the figure representing the level of funding needed to establish the Foundation. "It is difficult if not impossible for us to understand how things could have changed so dramatically in just under 3 years." However, during the Special Commission of Inquiry, this was found to have been far from the truth. The actuarial analyses provided to JH when it created the MRCF in 2001 were not comprehensive enough to reliably ascertain the amount required to fund the Foundation, ${ }^{32}$ nor were the assumptions used in arriving at the figures used in the calculations of the amount required independently checked, despite PWC having been retained apparently for that purpose. ${ }^{33}$

In November 2003, CEO Macdonald vehemently denied that the company was trying to avoid its asbestos-related liabilities when it established MRCF: "[the establishment of the Foundation was a] fair, transparent and legitimate action to provide certainty for claimants and shareholders". ${ }^{34}$ He continued to do so in April 2004, shifting blame towards the management of MRCF management

\footnotetext{
28 Merritt and Priest, "Dust-up".

29 James Hardie, "Possible Asbestos Funding Shortfall".

30 In 2001, Amaca Pty. Ltd. was adopted as the new name of the entity, James Hardie and Coy Pty. Ltd. This was the former operating entity of the Group during its asbestos manufacturing era and a subsidiary of the listed company, James Hardie Industries Ltd. The MRCF held 50\% of the shares in this entity with balance held by MRCF Investments Pty. Ltd.

31 Priest, "NSW Government".

32 Special Commission of Inquiry, Witness Transcript Reference 3261-3282.

33 Special Commission of Inquiry, Report, 57.

34 MacDonald, "Asbestos Compensation Fund Assertions", 67.
} 
for the huge increase in these liabilities in the three years since the Foundation was established. ${ }^{35}$ However, he retreated from this position when, under crossexamination before the Special Commission of Inquiry in June 2004, he agreed that the company received no outside expert financial advice on whether the MRCF would have sufficient funds to meet future claims. ${ }^{36}$ It was not surprising that when reporting the Inquiry's findings, Commissioner Jackson QC described the media release reproduced in Exhibit One as "a pure public relations construct, bereft of substance" ${ }^{37}$

These were by no means the only instances of avoidance strategy adopted by JH during this period. The 2001 Annual Report was issued a year before the public outcry associated with the revelation that the MRCF was significantly under-resourced. Asbestos-related liabilities are mentioned only once, in a note to the accounts in which the company distances itself from the issues completely and concludes that: "James Hardie does not currently anticipate that the effect of such laws, regulations, ordinances or claims will have a material adverse effect on its business, financial condition or results of operations" ${ }^{38}$ Corporate disclosures can be a potentially significant tool in managing legitimacy ${ }^{39}$ and in that annual report there is no mention of asbestos in the directors' review of operations, an astonishing omission given the situation that the company knew it was in, but it was consistent with a company that wished to avoid any discussion or focus upon the asbestos problem.

Thus, knowing that the MRCF was under-funded from the start, JH used a series of corporate disclosures in an effort to distance itself by deflecting attention while endeavouring to conceal the company's nonconformity with institutional expectations ${ }^{40}$ and so avoid future obligations for the under-funding of the Foundation.

\subsection{Defiance}

While avoidance is concerned with an entity distancing itself from the issues, defiance is a more active form of resistance to institutional pressures whereby the threatened entity begins to 'fight back'. In a situation where enforcement of rules is perceived as poor, the organisation may seek to dismiss, or ignore, the rules or values altogether. Oliver proposes three tactics of defiance. In order of escalating resistance: dismissal, challenge, and attack, ${ }^{41}$ all of which were employed by JH, particularly towards the end of the Special Inquiry in 2004 and during 2005 and 2006.

\footnotetext{
35 Macdonald, "James Hardie Will Rebut".

36 Special Commission of Inquiry, Witness Transcript Reference 2280-2664.

37 Special Commission of Inquiry, Report, 358.

38 James Hardie, 2001 Annual Report, 30.

${ }^{39}$ Merkl-Davies and Brennan, "Discretionary Disclosure Strategies".

${ }^{40}$ While the needs and expectations of diverse stakeholders such as the unions and shareholders may vary on matters such as wages and conditions of employment, it became clear that as the $\mathrm{JH}$ saga developed there was increasing agreement amongst most, if not all, of these groups that JH's efforts to quarantine itself from the asbestos legacy were unacceptable and needed to change. It follows that the institutional expectations were highly aligned on this key issue.

41 Oliver, "Strategic Responses", 156.
} 
Dismissal: some examples of this tactic were already mentioned in the previous section, including the claim in its 2001 Annual Report that it did not face any material threats and dismissal of any suggestion that any legal liability existed. In another instance of this approach, to counter a barrage of negative publicity concerning the MRCF, CEO Macdonald used a newspaper interview in March 2004 to state that the company had done "nothing that it wouldn't do again in the same circumstances", 42 effectively dismissing any criticism by implying that $\mathrm{JH}$ had done what anyone else would have done. Two weeks later, he reinforced his position, dismissing media coverage, alleging that it was biased against the company. ${ }^{43}$

Challenge: Following publication of the Inquiry's highly critical findings in September 2004, JH faced mounting political pressure to unconditionally fund all claims. It responded by reverting to a similar tactic to the one it had embraced in 2003, when it had confronted the New South Wales Government in the High Court. This time, it used a media release to challenge the Government to establish a statutory compensation fund for asbestos victims. ${ }^{44}$

Attack: Oliver noted that attacking actions seek to "assault, belittle, or vehemently denounce institutionalized values and the external constituents that express them." 45 In testimony to the Inquiry, the chairman of the MRCF accused JH of not providing sufficiently timely data for the Foundation to detect that it was underfunded and implied that it had been misled into assuming that the data supplied was the latest available. ${ }^{46} \mathrm{JH}$ denounced the claims and adopted 'assault' tactics, threatening to sue the Foundation if it sought to take legal action against the company. ${ }^{47}$

Related to the theme of defiance, the literature on defensive impression management techniques ${ }^{48}$ suggests that denial and justification are common strategies employed by organisations under siege. For example, Suchman discussed the tactic of formulating a normalising account. ${ }^{49}$ He contended that this approach, which is the one adopted by JH when it established the MRCF, seeks to separate the threatening revelation from larger assessments of the organisation as a whole. He argued that by retrospectively redefining means and ends, an organisation can seek to make an action seem morally acceptable.

However, such tactics are not likely to succeed unless they are seen to be sincere and valid and, by their very nature, may be counterproductive to perceived legitimacy of an entity if later developments contradict their substance. ${ }^{50}$ In the case of $\mathrm{JH}$, this is what occurred. Revelations about the known inadequacy of the funds set aside for claimants undermined JH's credibility, cast major doubts upon

\footnotetext{
42 Merritt, "Nothing to be ashamed".

43 Macdonald, "James Hardie Will Rebut".

44 James Hardie, "Regarding Special Commission Report".

45 Oliver, "Strategic Responses", 157.

${ }^{46}$ Special Commission of Inquiry, Witness Transcript Reference 79-190.

47 Special Commission of Inquiry, Exhibits 13-15.

48 See, for example, Suchman, "Managing legitimacy"; Ogden and Clarke, "Customer disclosures".

${ }^{49}$ Suchman, "Managing legitimacy", 598.

50 Ogden and Clarke, "Customer disclosures".
} 
the ethical integrity of its management and the validity of its other disclosures, and further diminished it reputational capital.

\subsection{Manipulation}

Oliver defined manipulation as the "purposeful and opportunistic attempt to coopt, influence, or control institutional pressures and evaluations". ${ }^{51}$ Throughout the period of this study, while concurrently adopting other strategies that varied according to the extent to which the situation facing the company altered, JH engaged in a continuous effort to manipulate politicians and the political process, and to influence the timing and tone of media reporting. An example of the latter can be found in an internal Board paper that recommended that the formation of the MRCF (that had occurred some months earlier) be announced simultaneously with the quarterly financial results for 2001, rather than as a separate media event because this would minimise the risk that "non-business media and perhaps other stakeholders would attend and hijack the briefing... this will enable us to announce the separation in a pure business context and set the agenda for public debate in this context" ${ }^{52}$ When publicly restated by CEO Macdonald during the Inquiry, there was no specific mention of the media. Instead, he simply stated that JH did not publicly announce the formation of the MRCF until several months after it had occurred because it sought to avoid the risk of opposition from unions, government and other stakeholders seeking to make the group. ${ }^{53}$

Concerning manipulation of politicians and the political process, JH paid former Federal Senator, Stephen Loosley, to act as a lobbyist on its behalf so as to utilise his political connections to introduce JH executives to key New South Wales government advisors. Moreover, he was to receive a contingency fee if JH's separation from its asbestos liabilities proceeded without legal opposition. ${ }^{54}$

CEO Macdonald's use of interviews to manipulate opinion have been described earlier in this paper and one of the clearest indications of JH's adoption of a manipulation strategy can be seen very early in the press releases it made during the period when the MRCF was being formed and then promoted. In particular, the press release issued in February 2001 announcing the formation of the MRCF utilised language and phrases, such as: 'substantial assets', 'sought expert advice' and 'provided certainty for both claimants and shareholders', all of which appear designed to provide reassurance to stakeholders but, as indicated earlier, they were for the most part a fabrication.

Finally, previous studies ${ }^{55}$ have found a positive association between disclosure levels and adverse media attention. As previously mentioned, there had been no disclosures at all about its asbestos liability in the 2001 Annual Report. In response to growing amounts of public disquiet, four years later the

\footnotetext{
51 Oliver, "Strategic Responses", 154.

52 Priest, "James Hardie's secret plan".

53 Special Commission of Inquiry, Witness Transcript Reference 2280-2664.

54 Special Commission of Inquiry, Witness Transcript Reference 2095-2116.

55 See, for example, Brown and Deegan, "Public disclosure".
} 
2005 Annual Report included eight pages on asbestos-related issues. This included extensive analysis of potential claims including an actuarial study; and, an update on the Heads of Agreement entered into with the New South Wales State Government, all presented in a way that presented a positive impression about the company and the situation it faced. Consistent with the impression management literature, ${ }^{56}$ the company also adopted a positive stance in its comments on the findings of the Inquiry. Coverage of asbestos-related issues increased to ten pages in the 2006 Annual Report, with 227 mentions of asbestos, along with the inclusion of the statement that "[the company] intends to proceed with fair and equitable actions to compensate the injured parties"; 57 and this high level and tone of disclosures continued in the 2007 Annual Report. However, in the 2006 Annual Report JH attempted to manipulate opinion by refusing to accept any responsibility for its involvement in asbestos, dismissing anything negative as being attributable to previous management, a recognised tactic in the crisis response literature. ${ }^{58}$ Remarkably, it did so despite the fact that the then Chairman, Meredith Hellicar, had been a Board member since 1992.

\subsection{Compromise}

In September 2004, the Commission concluded that CEO Macdonald had breached his duty as a director, that there was evidence he issued false and misleading statements to the Australian Securities Exchange, and that he was not a credible witness. ${ }^{59}$ The company management was ridiculed and the company was under siege, publically admonished by politicians, union leaders, and media commentators; and calls were being made for removal of its CEO and other senior officers. As noted by Priest, "mounting boycotts of its products, possible fraud charges against senior executives, blanket media coverage and the return of political donations meant the company brand was suffering heavy damage."60

The company's response to these increasing institutional pressures represented a clear change in strategy. Avoidance and defiance gave way to attempts to pacify, to demonstrate contrition, and promises to seek a more equitable solution, all led by a shift in stance in its communications towards being more balanced and more willing to listen and respond. In an attempt to pacify its critics, it invoked a change of leadership, but not with an outsider, and no changes were made to the appointments of CEO Macdonald or any other senior members of the Board. This astonishing lack of recognition of the extent to which the public image of its management had been destroyed by the findings of the Inquiry was, perhaps, unsurprising given the ability the company had exhibited in managing to ignore the obvious in the face of overwhelming evidence, but at least some changes had been made. The compromising had begun.

\footnotetext{
${ }^{56}$ For example, Neu, Warsame, and Pedwell, "Managing public impressions"; Ogden and Clarke, "Customer disclosures".

57 James Hardie, 2006 Annual Report, 105.

58 Coombs, "Conceptualizing crisis communication".

${ }^{59}$ Special Commission of Inquiry, Report, 366.

60 Priest, "Hardie backdown", 6.
} 
On 11 August, 2004, Meredith Hellicar, was announced as the new Chairman of the Joint Board and Supervisory Board, ${ }^{61}$ replacing Alan McGregor who was undergoing treatment for lymphoma. Hellicar immediately became the highly visible media voice of James Hardie, adopting a very contrite tone in her public pronouncements and making the outcry concerning the MRCF her first target. Apologies for past actions would be expected as a response to public pressures arising from adverse environmental press ${ }^{62}$ and less than a week after becoming Chairman, on 16 August Hellicar apologized to claimants for the 'manifest underfunding' of the MRCF and stated that the Board was 'totally committed' to ensuring proper compensation for all victims. Whereas formerly the focus had been on 'legal obligations', for the first time JH began to talk about 'moral obligations' 63 and 'moral responsibility' and of how the Board of JH wanted to increase funding to the MRCF because, as stated by Hellicar, it was "what we morally want to do".64 In the following month, Hellicar continued to present this conciliatory tone:

Speaking about the under-funded MRCF on 17 August 2004, she again apologised: "I can do no more than say sorry. At the end of the day, it was underfunded." 65

\section{"I think hindsight would say that there are a lot of lessons learnt."66}

“... there's absolutely no doubt that the foundation was significantly underfunded and the board takes responsibility for that ... frankly, we are all up for re-examination and I don't exclude myself from this." 67

"I agree I think we did misjudge the public attention that would be brought upon us ... we have been caught in a storm of publicity ... it is going to take us a long time to restore our credibility and reputation." 68

Meanwhile, on 13 August, two days after the announcement of Hellicar's appointment, and also the final day of the Inquiry Hearings, the company's barrister announced that it had agreed to open-ended compensation for all future victims of its products, subject to new legislation capping legal costs and without admitting legal liability. Although extremely limited and ignorant of present claimants, this change in attitude was acknowledged by the Australian Council of Trade Unions (ACTU) that, until then, had been an ardent critic of the company's tactics and had led the boycott of its products. The then ACTU secretary, while questioning the details, called the move a 'real breakthrough' as JH now "accepted their obligation to compensate all victims". ${ }^{9}$

\footnotetext{
61 James Hardie, "New Chairman appointed".

62 O’Donovan, "Managing legitimacy".

63 ABC, "TV Program Transcript".

${ }^{64}$ Buffini and Pretty, "Hardie's new tactic".

65 ABC, "TV Program Transcript".

66 Buffoni, "Hellicar vows".

67 Buffini and Stafford, "New Hardie offer".

68 Buffini and Stafford, "New Hardie offer".

${ }^{69}$ Combet, "James Hardie Media Conference".
} 
The company's initial attempt to resist calls for its senior executives to resign by installing Helliar as the Chairman had not had the impact it had hoped. A further attempt at placating its critics came seven weeks later, on September 28, 2004, when JH announced that its CEO and its CFO had both been deposed although, in the spirit of compromise, ex-CEO Macdonald retained his pay and an ongoing "responsibility for business operations".70

JH was also engaged in negotiations with key stakeholders, attempting to strike a bargain that would satisfy their demands. On December 21, 2004 it announced that it had entered into a voluntary agreement negotiated with key stakeholders including asbestos sufferers, the ACTU, and the New South Wales Government, "which is expected to form the basis of a proposed binding agreement (the "Principal Agreement") to establish and fund a special purpose fund (the "SPF") to provide funding on a long-term basis for asbestos-related injury and death claims (the "Claims") against Amaca, Amaba, and ABN 6071 ...".72 A year later, on 1 December 1, 2005, it entered into a conditional agreement with the New South Wales Government. This was then amended on 21 November 2006. The company asked its shareholders to ratify the agreement on 12 December 2006, justifying its position in an Explanatory Memorandum:

“... the contribution of funding on a voluntary basis in response to such a shortfall is consistent with investor and Australian community expectations; and James Hardie is at risk of having potential adverse action taken against it by governments, unions and consumers if it does not provide a response to the estimated future funding shortfall which is acceptable to the NSW Government, the Australian Government, the ACTU, Unions NSW and Asbestos Diseases Groups. While it is not possible to predict the precise nature or impact of such actions, it is possible that these actions could, individually or cumulatively, have a significant adverse effect upon James Hardie's profitability, results of operation and reputation, particularly with respect to its Australian based operations."73

However, it prefaced this statement by once again asserting that, from a legal perspective, it had no cause to do so: "James Hardie believes that under current law James Hardie has no present legal liability to meet the liabilities of the Former James Hardie Companies, except to the limited extent previously agreed to by James Hardie". ${ }^{74}$

A voluntarily agreement had been reached by the company with its key stakeholders that was justified by $\mathrm{JH}$ on moral and business grounds and, as revealed elsewhere in the memorandum, JH was confident that the benefits of agreeing to paying compensation outweighed the costs of doing so. It had not

\footnotetext{
70 Buffini and Stafford, "New Hardie offer".

${ }^{71}$ ABN 60 was formerly known as James Hardie Industries Ltd. Amaca was known as James Hardie and Coy Pty. Ltd.. Amaba Pty. Ltd. was known as Jsekarb Pty. Ltd.. The names of these three entities were all changed in February 2001. Together these entities housed the asbestos obligations of the Group.

72 James Hardie, 2005 Annual Report, F-26.

73 James Hardie, Explanatory Memorandum, 2.

74 James Hardie, Explanatory Memorandum, 2.
} 
capitulated, nor acquiesced. Rather, it had compromised: pacifying and bargaining in an attempt to balance the internal interests of the company with those of multiple stakeholders. Oliver suggests that compromise is done in a "spirit of conforming to and accommodating institutional rules, norms, or values"75 and these are acknowledged in the Explanatory Memorandum. However, as revealed in that document, the company was still negotiating tax breaks for its compensation payments, still denying liability, and only going so far as it felt it had to in terms of cost and benefits to the company, all of which is in line with Oliver's view that "institutional compliance is only partial and organizations are more active in promoting their own interests". ${ }^{6}$ The shareholders approved the recommendations in February 2007.

\subsection{Overall}

At no stage did the company acquiesce, admit it was responsible for the results of its actions, and accept that it had to make full restitution for what had occurred. By adopting these tactics, the company secured its survival, but those involved in the subterfuge did not escape unpunished. In 2009, former CEO Macdonald, who had received AU\$8.8 million from JH when he resigned in 2004, was fined AU $\$ 350,000$ and given a 15-year ban from serving as a company director. The company's former General Council was fined AU $\$ 79,000$ and given a 7 year ban; and the former CFO was fined AU\$35,000 and a 5-year ban. Seven other senior executives, including former Chairman Hellicar, ${ }^{77}$ were also found guilty of breaching their duties to the company in 2001 over the MRCF media release. They appealed, but the verdicts and punishments were upheld in the High Court in 2012, with former Chairman Hellicar and the six other former Board members each fined AU\$30,000 and given a 5-year ban.

The actions of JH can also be interpreted by reference to its crisis management and crisis response communications.

\section{Crisis Management and Crisis Response Communications}

\subsection{Crisis Management}

Crisis management emphasises the value of reputations. ${ }^{78}$ Organizations accumulate reputational capital over time, as JH did at least until the 1970s, and arguably for some time thereafter. It became a household name, well-respected, an exemplar of excellent business practices. If an event is considered to be 'offensive', such as the impact of JH's use of asbestos on people's health, it can become a crisis, ${ }^{79}$ as can a seemingly harmless event that is not handled appropriately. ${ }^{80}$ According to De Maria, a post-scandalised organisation, such as $\mathrm{JH}$, has three choices: become a redemptive organisation; tread water; or slip

\footnotetext{
75 Oliver, "Strategic Responses", 154.

76 Oliver, "Strategic Responses", 154.

77 Hellicar had resigned as Chairman in 2007.

78 Coombes, "Protecting organization reputations".

${ }^{79}$ Benoit, Accounts, Excuses, and Apologies.

${ }^{80}$ Coombes, "Protecting organization reputations".
} 
into becoming a rogue organisation. ${ }^{81} \mathrm{JH}$ 's response to a growing sense of outrage in the late 1990 s was to tread water, to maintain a policy of denial, to refuse to settle any claim for compensation, and to distance itself from liability by restructuring the organisation, relocating its operations overseas, and forming the MRFC. When the underfunding of the Trust became public knowledge, JH's loss of reputational capital was complete. It had become a public disgrace, a company in crisis and immersed in scandal. Its management had been shown to be deceitful and manipulative and unable to be trusted. To secure its survival, an organisation in crisis must be perceived to be ready to move to a post-crisis phase of rebuilding its standing showing a level of remorse that is sufficiently effective for stakeholders to believe that it has absorbed the lessons from its mistakes. ${ }^{82}$ This is what JH then endeavoured to do by entering into the negotiations that led to the Amended and Final Funding Agreement in 2007.

\subsection{Crisis Communications}

Pre-crisis, organisations engage in prevention and planning communication activities, but once a crisis occurs, a different form of communication must be adopted: response. "The central goals of crisis response communication reflect those of crisis management:(1) preventing or minimizing damage,(2) maintaining the organization's operations (business continuity), and (3) reputation repair". ${ }^{83}$ Generally, the media frames the crisis and this is what most stakeholders will encounter and accept, which is why it is imperative that the organisation ensures that it uses the media to present its version of events and to firmly state its position. Borrowing from the impression management literature and, in particular Allen and Callouet, ${ }^{84}$ Coombs presents a range of fundamental organisational crisis response communication strategies, including attacking the accuser; asserting that there is no crisis; blaming some person or group outside of the organization for the crisis; compensating victims through offers of money or other gifts; and, apologising and stating that the organization takes full responsibility for the crisis. ${ }^{85}$ As shown in this study, JH adopted all these crisis response communication tactics, but waited until all other tactics had failed before apologising. It never admitted full responsibility.

Overall, JH's crisis management tactics combined with its crisis response communication strategy were successful in slowing the wave of antagonism and outrage it faced and, while its reputation was left in pieces, it salvaged sufficient of it to be able to continue in business where other businesses elsewhere did not. But, what was it that drove JH to delay so long, to wait until it was facing complete destruction before acting to restore trust and public sentiment through apology and compromise? This is explored in the next section.

\footnotetext{
81 De Maria, "After the scandal”.

82 Benoit, Accounts, Excuses, and Apologies; Coombs, "Protecting organization reputations"; De Maria, "After the scandal"; Grebe, "Things can get worse".

83 Coombs, "Conceptualizing crisis communication", 105.

${ }^{84}$ Allen and Callouet, "Legitimation endeavors".

85 Coombs, "Protecting organization reputations"; Coombs, "Conceptualizing crisis communication".
} 


\section{What factors motivated the actions taken by James Hardie?}

In addition to defining the five forms of organisational reaction to pressures toward conformity utilised in this study, Oliver also proposed that these could be applied in a predictive model that indicates the likelihood of organisational resistance based on boundaries relating to the willingness and ability of organisations to conform and the costs and benefits, including affects on legitimacy, of doing so. ${ }^{86}$ Oliver's model is founded upon the similarities and differences between the predicted response of an organisation to institutional pressures as indicated by institutional theory compared with those indicated by resource-based theories of organisational behaviour. It contains 10 predictive dimensions, five of which - 1, 2, 3, 6, and 9 - are most likely to exhibit the greatest extreme directional relationship between the causal factor and choice of a resistance-focused strategy - avoidance, defiance, or manipulation - rather than compromise or acquiescence: 87

1: The lower the degree of social legitimacy perceived to be attainable from conformity to institutional pressures, the greater the likelihood of organisational resistance to institutional pressures. ${ }^{88}$

2: The lower the degree of economic gain perceived to be attainable from conformity to institutional pressures, the greater the likelihood of organizational resistance to institutional pressures. ${ }^{89}$

3: The greater the degree of constituent multiplicity (i.e. multiple, conflicting, constituent expectations exerted on an organization), the greater the likelihood of organizational resistance to institutional pressures. 90

6: The greater the degree of discretionary constraints (i.e. greater the loss of decision-making discretion) imposed upon the organization by institutional pressures, the greater the likelihood of organizational resistance to institutional pressures. ${ }^{91}$

9: The lower the level of uncertainty in the organization's environment (i.e. the degree to which future states of the world cannot be anticipated and accurately predicted), the greater the likelihood of organizational resistance to institutional pressures. ${ }^{92}$

In the case of $\mathrm{JH}$, it can be seen that a pivotal instance occurred at the conclusion of the Special Commission of Inquiry. The company's failure to compromise up to that point and its switch to a compromise strategy thereafter can be explained, at least in part, using these five dimensions. Firstly, its reputational capital, its legitimacy in the eyes of its stakeholders, could not have

\footnotetext{
86 Oliver, "Strategic Responses".

${ }^{87}$ Oliver, "Strategic Responses", 159-172.

88 Oliver, "Strategic Responses", 160.

89 Oliver, "Strategic Responses", 160-161.

90 Oliver, "Strategic Responses", 162.

91 Oliver, "Strategic Responses", 164.

92 Oliver, "Strategic Responses", 170.
} 
been lower in the periods before and after its adoption of a compromise strategy. After over 70 years involvement in asbestos, during at least 50 of which it had known of the dangers of asbestos dust, any tangible improvement in its legitimacy by its acquiescing was unlikely and certainly insufficient to encourage it to change its strategy away from Oliver's hypothesised (Dimension 1) position of resistance. At the point of imminent disclosure of the Boards duplicity by the Special Commission of Inquiry in 2004, other factors began to dominate, each of which led to the adoption of a strategy of compromise.

Any potential for economic gain attainable by acquiescence (Dimension 2) was inconceivable. However, once it became clear that survival would only be possible if it began to compromise, it did so by seeking an agreement that would minimise the resulting economic losses, something it made clear in its Explanatory Memorandum to its shareholders in 2006. Similarly, nor did the fact that most of its stakeholders were united against it from the beginning of this period cause JH to change its position to one of acquiescence, because of the threat of significant economic losses if it did so. However, when it was clear that the view was unanimous (Dimension 3) it was left with no choice but to shift towards a compromise that might minimise the economic losses it faced.

JH had long before diversified into other markets, in which it was operating successfully. In that respect, it had considerable decision-making discretion (Dimension 6). However, it did face product boycotts in its traditional Australian markets, and chose to combat those with resistance strategies; and it faced a very uncertain environment relating to its future asbestos liabilities when it formed the MRCF (Dimension 9). Once it became aware of the findings of the Special Commission of Inquiry, it would have envisaged, both that the next step would be legislative and that it would have no support in limiting the extent to which sanctions were imposed. At that point, the future outlook became clearly one of no future unless it started to concede its position. A switch to a compromise strategy was its only option.

As to how this resonates with the theories upon which Oliver built her model, institutional theory posits that numerous aspects of formal organisational structure, policies, and procedures result from prevailing societal attitudes towards what comprises acceptable practice in the eyes of important constituents..$^{93}$ Organisations tend to obey these rules, requirements and norms, not necessarily for reasons of efficiency, but in order to enhance their legitimacy, resources, and capacity for survival. ${ }^{94}$ Resource-based theories suggest that, "in general, organizations will tend to be influenced by those who control the resources they require" and, directly relevant to $\mathrm{JH}$, that among other factors "the focal organization [must be] capable of developing actions or outcomes that will satisfy the external demands... [and] desires to survive". ${ }^{95}$ Consistent with both these branches of theory, it was a desire to survive that drove James Hardie to finally

\footnotetext{
93 DiMaggio and Powell, "The Iron Cage Revisited"; Scott, "The Adolescence”; Bealing, Dirsmith, \& Fogarty, "Early Regulatory Actions".

94 Kondra and Hinings, "Organizational Diversity".

95 Pfeffer and Salancik, "External Control of Organisations", 44
} 
adopt a strategy of compromise and apologetic communication to manage the potentially terminal crisis it faced.

\section{Conclusions}

This case study of the James Hardy asbestos controversy builds upon the work of Moerman et al., ${ }^{96}$ which dealt with the period preceding the time examined here. During the shorter, but more concentrated period of this study, the potential liabilities emerged and crystallised. Four research questions framed this study. The actions taken by JH were identified (RQ1) and the factors that motivated them were explored (RQ3), along with its changing pattern of public disclosures (RQ2) that were considered in the context of the literature on crisis management and crisis communications (RQ4).

From a corporate communications perspective, ${ }^{97} \mathrm{JH}$ 'got it wrong'. Most stakeholders perceive a crisis on the basis of how something is framed by the media. An otherwise appropriate crisis management strategy may only succeed if its crisis communications strategy is capable of shaping the message being conveyed in the media so that it looks favourably upon the focal organisation. The tobacco industry did so successfully for many years by framing messages built around casting uncertainty over the impact of smoking on health, making statements and commitments to consumers about the legitimate concern that tobacco companies had for the overall health of their customers and then being seen as a strong advocate for the rights of smokers. ${ }^{98}$

In contrast, JH's efforts to understate its culpability and minimise its financial obligations could be compared to how others would categorise the components of a shopping list, with pragmatic indifference. Remaining defiant in the face of a barrage of negative news reports, relying on the advice of legal counsel over public relations, its statements and disclosures reflected an attitude that was unemotional, distant, conservative, and parsimonious. ${ }^{99}$ In doing so, it failed to convince its stakeholders that its version of what had occurred was anything but subterfuge and an unacceptable denial of responsibility. As a result, it did not succeed in deflecting attribution of the crisis, it failed to change negative perceptions of the organisation flowing from the crisis, and it did not manage to reduce the negative impact generated by the crisis. Its resistance tactics only compounded the crisis, strengthening resolve that the harm suffered by its victims was not accidental, nor unintentional, nor uncontrollable, but intentional and purposeful.

JH finally acknowledged the need to change its strategy to one of compromise and remorse when the damming findings of the Special Commission of Inquiry were about to be released, threatening its survival unless it did so. This led to its negotiating an entirely new structure for compensating asbestos victims from future corporate earnings; and undergoing strategic restructuring,

\footnotetext{
96 Moerman, van der Laan, and Campbell, "A Tale".

97 For example, Coombs and Holladay "Helping crisis managers"; Grebe, "Things can get worse".

98 Derry and Waikar, Frames and filters".

${ }^{99}$ Black, Essentials of Public Relations.
} 
seeking to repair its organisational legitimacy through executive replacement ${ }^{100}$ by appointing a new Chairman, replacing key employees including the CEO and CFO, and revamping the Board of Directors.

Economic factors drove all the actions taken by JH. Initially, a desire to ringfence the company to protect it from its asbestos-related liability motivated the formation of MRCF. The selection of response strategies thereafter continued to be driven by what was perceived as being the best approach to minimise the economic costs to the company. When survival became the primary concern, it too was pursued in a manner intended to minimise the economic cost to the company. In comparison, during the period of this study, companies subject to similar claims in the UK and the US were undergoing strategic bankruptcies in order to survive as best they could. One of the key contributions of this study to the literature on company crises and company failure is how $\mathrm{JH}$, faced with potentially terminal decline resulting from the costs of claims it might face, chose to adopt delaying strategies rather than Chapter 11-type immolation and, as a result, survived intact at the end of the process. Yet, while JH's use of crisis management and crisis communications strategies ultimately secured its survival, they were significantly less effective than those of some other major companies that have faced potentially destructive corporate crises. Notably, Shell's discourse through major scandals, moved it "from a taken-for-granted discourse of economic development [to one that] attempts to balance interests of economic development with environmental well-being... [and] opened itself to such potentially democratizing discursive forms as stakeholder engagement, dialog, and social reports". ${ }^{101} \mathrm{Had} \mathrm{JH}$ adopted a similar approach to Shell, it too may have avoided many of the adverse consequences upon the company that arose from the asbestos scandal.

\section{Limitations}

This study relies upon archival evidence drawn from the public domain, such as annual report and other media disclosures by the company and the testimonies and pronouncements that emerged during the Special Commission of Inquiry. No access was available to the private deliberations of the Board of Directors and the management of $\mathrm{JH}$ in determining their strategic approaches to the asbestos issues. Notwithstanding this limitation, the major strategic initiatives pertaining to this issue seem to be readily observable by analysing the words and actions of JH's key personnel and, in particular, the evidence provided at the Special Commission of Inquiry.

\section{Disclosure statement}

No potential conflict of interest was reported by the authors.

\section{Notes on Contributors}

Brendan O'Connor is Professor...

\footnotetext{
100 Suchman, "Managing legitimacy", 598.

101 Livesey, "Eco-identity", 59.
} 
Alan Sangster is Professor of Accounting at the University of Sussex. His research interests are in accounting in late-Medieval and Renaissance Italian business practice and business education (c.1200-1700); the history of breweries, family businesses, and entrepreneurship; and in accounting education: teaching, leaning, assessment, and faculty. Among his recent publications are Libr. XV: Cotrugli and de Raphaeli on Business and Bookkeeping in the Renaissance, Lomax Press 2014; and "The Genesis of double entry bookkeeping" in The Accounting Review (2016).

Greg Stoner is Senior lecturer...

Paul de Lange is...

\section{References}

\section{Primary}

James Hardie Industries. Amended and Restated Final Funding Agreement N.V, 21 November, 2006. Sydney: Gilbert Tobin Lawyers. Accessed June 12, 2015. www.irasia.com/listco/au/jameshardie/announcement/06index.htm

James Hardie. Annual Reports 2001 to 2007. Accessed June 12, 2015. www.ir.jameshardie.com.au/jh/artable.jsp

James Hardie. Explanatory Memorandum. Amsterdam: James Hardie Industries N.V, 2006.

James Hardie Media Release. 2003. Possible Asbestos Funding Shortfall Suggests Significant Change in Claims, October 29; Accessed November 20, 2015. http://www.ir.jameshardie.com.au/public/download.jsp?id=1171

James Hardie Media Release. 2004a. New Chairman appointed to JHI NV. August 11. Accessed June 13, 2015.

http://www.ir.jameshardie.com.au/public/download.jsp?id=1151

James Hardie Media Release. 2004b. James Hardie Statement Regarding Special Commission of Inquiry Report, September 21. Accessed November 20, 2015. http://www.ir.jameshardie.com.au/public/download.jsp?id=1424

Special Commission of Inquiry into the Medical Research and Compensation Foundation. "Report. Commissioner D.F. Jackson, Q.C., September." Sydney: Government of the State of New South Wales, 2004.

Special Commission of Inquiry into the Medical Research and Compensation Foundation. "Exhibits 13-15." Sir Llewellyn Edwards, Commissioner D.F. Jackson, Q.C." Sydney: Government of the State of New South Wales, 2004.

Special Commission of Inquiry into the Medical Research and Compensation Foundation. "Witness Transcript Reference 3261-3282. Julian Minty, 
Commissioner: D.F. Jackson, Q.C., 23 April to 30 June." Sydney: Government of the State of New South Wales, 2004.

Special Commission of Inquiry into the Medical Research and Compensation Foundation. "Witness Transcript Reference 2280-2664. Peter Macdonald, Commissioner: D.F. Jackson, Q.C., 1 June to 8 June." Sydney: Government of the State of New South Wales, 2004.

Special Commission of Inquiry into the Medical Research and Compensation Foundation. "Witness Transcript Reference 79-190. Dennis Cooper, Commissioner: D.F. Jackson, Q.C., 5 April to 7 April." Sydney: Government of the State of New South Wales, 2004.

Special Commission of Inquiry into the Medical Research and Compensation Foundation. "Witness Transcript Reference 2095-2116. Stephen Loosley, Commissioner: D.F. Jackson, Q.C., 27 May.” Sydney: Government of the State of New South Wales, 2004.

\section{Secondary}

ABC [Australian Broadcasting Corporation]. "TV Program Transcript." August 17, 2004. http://www.abc.net.au/7.30/content/2004/s1178823.htm

Allen, M.W., and R.H. Caillouet. "Legitimation endeavors: Impression management strategies used by an organization in crisis." Communications Monographs 61, no. 1 (1994): 44-62.

Allens Arthur Robinson. Special Commission of Inquiry into the Medical Research \& Compensation Foundation: Submissions of James Hardie Industries NV and ABN 60 Pty Limited on Terms of Reference 2 \& 3. Sydney: Allens Arthur Robinson, 2005.

Arroyo, P. "Management accounting change and sustainability: an institutional approach." Journal of Accounting \& Organizational Change 8, no. 3 (2012): 286-309.

Asbestos Diseases Society of Australia. Asbestos: what you should know (4th Edition). Fitzroy: Asbestos Diseases Society of Australia Inc., 2003. Accessed January 9, 2014.

https://www.slatergordon.com.au/files/editor_upload/File/Book\%20edition \%204\%20FINAL.pdf

ASCC [Australian Safety and Compensation Council]. Asbestos management and control: a review of national and international literature. Canberra: ASSC, 2008.

Bealing, W.E., M.W. Dirsmith, and T. Fogarty, T. "Early Regulatory Actions by the SEC: An Institutional Theory Perspective on the Dramaturgy of Political Exchanges." Accounting, Organisations and Society 21, (1996): 317-338. 
Benoit, W. L. Accounts, Excuses, and Apologies: A Theory of Image Restoration. Albany: State University of New York Press, 1995.

Black, S. The Essentials of Public Relations. London: Kogan Page, 1993.

Bradford, J.L., and D.E. Garrett. "The effectiveness of corporate communicative responses to accusations of unethical behaviour." Journal of Business Ethics 14, (1995): $875-892$.

Brown, N., and C.M. Deegan. "The public disclosure of environmental performance information - a dual test of media agenda setting theory and legitimacy theory." Accounting and Business Research 29, (1998): 21-41.

Buffini, F. 2004. "Hellicar vows to restore Hardie's Honour." The Australian Financial Review, September 16, 3.

Buffini, F., and M. Pretty. 2004. "Hardie's new tactic: we're sorry." The Australian Financial Review, August 17, 1.

Buffini, F., and A. Stafford. 2004. "New Hardie offer as chief steps aside." The Australian Financial Review, September 29, 1.

Combet, G. 2004. James Hardie Media Conference on behalf of the Australian Council of Trade Unions held on 13 August. Reported in Buffini, F. "Hardie signals full payout to victims." The Australian Financial Review, August 14, 1.

Coombs, W. T. "Conceptualizing crisis communication." In Handbook of risk and crisis communication, edited by R.L. Heath, and H.D. O'Hair, 99-118.

Abingdon: Routledge, 2009.

Coombs, W.T. "Protecting organization reputations during a crisis: The development and application of situational crisis communication theory." Corporate Reputation Review 10, no. 3 (2007): 163-176.

Coombs, W.T., and S.J. Holladay. "Helping crisis managers protect reputational assets: Initial tests of the situational crisis communication theory." Management Communication Quarterly 16, (2002): 165 - 186.

Cornelissen, J., T. Bekkum, and B. Ruler. "Corporate communication: A practisebased theoretical conceptualisation." Corporate Reputation Review 9, (2006): 114-123.

De Maria, W. "After the scandal - recovery options for damaged organizations." Journal of Management \& Organization 16, no. 1 (2010): 66-82.

Derry, R., and S.V. Waikar. "Frames and filters." Business and Society 47, no. 1 (2008): 102-139.

DiMaggio, P.J., and W.W. Powell. "The Iron Cage Revisited: Institutional Isomorphism and Collective Rationality in Organizational Fields." American Sociological Review 48, (1983): 113-123. 
Grebe, S.K. “Things can get worse." Corporate Communications 18, no. 1 (2013): 70-86.

Guerreiro, M. S., L.L. Rodrigues, and R. Craig. "Voluntary adoption of IFRS by large unlisted companies in Portugal - Institutional logics and strategic responses." Accounting, Organizations and Society 37, no. 7 (2012): 482-499.

Haigh, G. Asbestos House: The Secret History of James Hardie Industries. Carlton, Victoria: Scribe Publications, 2006.

Higgins, E. 2014. "Hardie boss David Macfarlane thought asbestos risk a 'beatup'." The Australian, April 8.

Jeremy, D.J. "Corporate Responses to the Emergent Recognition of a Health Hazard in the UK Asbestos Industry: The Case of Turner \& Newall, 19201960." Business and Economic History 24, no. 1 (1995): 254-265.

Kondra, A.Z., and C.R. Hinings. "Organizational Diversity and Change in Institutional Theory.” Organization Studies 19 (1998): 743-767.

Livesey, S.M. "Eco-identity as discursive struggle: Royal Dutch/Shell, Brent Spar and Nigeria." Journal of Business Communication 38 (2001): 58-91.

Macdonald, P. 2003. "Asbestos Compensation Fund Assertions Offensive." The Australian Financial Review, November 3, 67.

Macdonald, P. 2004. "James Hardie Will Rebut Allegations." The Australian Financial Review, April 30, 79.

Merkl-Davies, D.M. and N.M. Brennan. "Discretionary Disclosure Strategies in Corporate Narratives: Incremental Information or Impression Management?" Journal of Accounting Literature 26 (2007): 116-194.

Merritt, C. 2004. "Nothing to be ashamed of, says CEO." The Australian Financial Review, March 16, 3.

Merritt, C., and M. Priest. 2003. "Dust-up over asbestos shortfall.” The Australian Financial Review, October 30, 4.

Modell, S., K. Jacobs, and F. Wiesel. "A process (re)turn?: Path dependencies, institutions and performance management in Swedish central government." Management Accounting Research 18 (2007): 453-475.

Moerman, L., \& van der Laan. (2012). Accounting and Long-tail Liabilities: The Case of Asbestos. Research Report 130. United Kingdom: ACCA, 2012

Moerman L., and S. van der Laan. "Accounting in organizations: a strategy for asbestos liabilities." Working paper, Universities of Wollongong and Sydney, 2011. 
Moerman L., and S. van der Laan. "Pursuing shareholder value: The rhetoric of James Hardie.” Accounting Forum 31 (2007): 354-369.

Moerman L., and S. van der Laan. "Strategic Bankruptcy: The Case of James Hardie." Paper presented at the $9^{\text {th }}$ Interdisciplinary Perspectives on Accounting Conference, Innsbruck, Austria, July 11, 2009.

Moerman, L., S. van der Laan, and D. Campbell. "A tale of two asbestos giants Corporate reports as (auto)biography.” Business History 56 (2014): 975-995.

Neu, D., H. Warsame, and K. Pedwell. "Managing public impressions: environmental disclosures in annual reports." Accounting, Organisations and Society 23 (1998): 265-282.

O'Donovan, G. "Managing legitimacy through increased corporate reporting: an exploratory study." Interdisciplinary Environmental Review 1 (1999): 63-99.

Ogden, S., and J. Clarke. "Customer disclosures, impression management and the construction of legitimacy. Corporate reports in the UK privatised water industry." Accounting, Auditing \& Accountability Journal 18 (2005): 313-345.

Oliver, C. "Strategic Responses to Institutional Processes." Academy of Management Review 16 (1991): 145-179.

Pfeffer, J., and G.R. Salancik. External Control of Organisations. New York: Harper and Row, 1978.

Priest, M. 2003. "NSW Government Has Good Reason To Consider Reform." The Australian Financial Review, October 30, 4.

Priest, M. 2004a. "James Hardie's secret plan to spin the media and the politicians." The Australian Financial Review, May 15, 23.

Priest, M. 2004b. "Hardie backdown leaves many questions." The Australian Financial Review, August 14, 6.

Ribeiro, J.A., and R.W. Scapens. "Institutional theories and management accounting change: contributions, issues and paths for development." Qualitative Research in Accounting and Management 3, no. 2 (2006): 94-111.

Samkin, G., and A. Schneider. "Accountability, narrative reporting and legitimation. The case of a New Zealand public benefit entity." Accounting, Auditing \& Accountability Journal 23 (2010): 256-289.

Scott, W. R. "The Adolescence of Institutional Theory." Administrative Science Quarterly 32 (1987): 493-511.

Sexton, E., and T. Stephens. 2004. "Lives in the Dust." The Sydney Morning Herald, September 25, 27. 
Suchman, M.C. "Managing legitimacy: Strategic and institutional approaches." Academy of Management Review 20 (1995): 571-610.

Tweedale, G., and P. Hansen. "Protecting the workers: The Medical Board and the asbestos industry, 1930s-1960s.” Medical History 42 (1998): 439-457.

Tweedale, G., and D.J. Jeremy. "Compensating the Workers: Industrial Injury and Compensation in the British Asbestos Industry, 1930s-60s." Business History 41, no. 2 (1999): 102-120.

Tweedale, G., and R.C. Warren. "A Case in Point- Morality and Paternalism in the Asbestos Industry - A Functional Explanation." Business Ethics: A European Review 7, no. 2 (1998): 87-96.

Ville, S., and D.T. Merrett. "The Development of Large Scale Enterprise in Australia, 1910-64." Business History 42, no. 3 (2000): 13-46.

Warren, R.C. "The Enforcement of Social Accountability - Turner and Newall and the Asbestos Crisis." Corporate Governance 5, no. 2 (1997): 52-59. 